\title{
Correction to: High dose rate intra-cavitary brachytherapy with cobalt 60 source for locally advanced cervical cancer: the Zimbabwean experience
}

\author{
Shirley Chibonda ${ }^{1 *}$, Ntokozo Ndlovu² ${ }^{2}$ Nomsa Tsikai ${ }^{2}$, Lameck Munangaidzwa ${ }^{3}$, Sandra Ndarukwa ${ }^{4}$, \\ Albert Nyamhunga ${ }^{1}$ and Tinashe Mazhindu ${ }^{2}$
}

\section{Correction to: Infect Agents Cancer 16, 1 (2021) https://doi.org/10.1186/s13027-020-00340-5}

The original publication [1] of this article was published with an incorrect title. In this correction article the incorrect and correct title are shown, the original publication has been updated.

Incorrect

- Working title: high dose rate intra-cavitary brachytherapy with cobalt 60 source for locally advanced cervical cancer: the Zimbabwean experience

\section{Correct}

- High dose rate intra-cavitary brachytherapy with cobalt 60 source for locally advanced cervical cancer: the Zimbabwean experience

\section{Author details}

${ }^{1}$ Parirenyatwa Hospital Radiotherapy and Oncology Centre, Harare,

Zimbabwe. ${ }^{2}$ Department of Oncology, University of Zimbabwe Faculty of Medicine and Health Sciences, Harare, Zimbabwe. ${ }^{3}$ Department of Statistics, National AIDS Council of Zimbabwe, Harare, Zimbabwe. ${ }^{4}$ Department of Oncology, Sally Mugabe Central Hospital, Harare, Zimbabwe.
Published online: 11 February 2021

\section{Reference}

1. Chibonda S, Ndlovu N, Tsikai N, et al. Working title: high dose rate intracavitary brachytherapy with cobalt 60 source for locally advanced cervical cancer: the Zimbabwean experience. Infect Agents Cancer. 2021;16:1 https://doi.org/10.1186/s13027-020-00340-5.

The original article can be found online at https://doi.org/10.1186/s13027020-00340-5

*Correspondence: shirley.katsande@gmail.com

'Parirenyatwa Hospital Radiotherapy and Oncology Centre, Harare, Zimbabwe

Full list of author information is available at the end of the article

C C The Author(s). 2021 Open Access This article is licensed under a Creative Commons Attribution 4.0 International License, which permits use, sharing, adaptation, distribution and reproduction in any medium or format, as long as you give appropriate credit to the original author(s) and the source, provide a link to the Creative Commons licence, and indicate if changes were made. The images or other third party material in this article are included in the article's Creative Commons licence, unless indicated otherwise in a credit line to the material. If material is not included in the article's Creative Commons licence and your intended use is not permitted by statutory regulation or exceeds the permitted use, you will need to obtain permission directly from the copyright holder. To view a copy of this licence, visit http://creativecommons.org/licenses/by/4.0/ The Creative Commons Public Domain Dedication waiver (http://creativecommons.org/publicdomain/zero/1.0/) applies to the data made available in this article, unless otherwise stated in a credit line to the data. 